\title{
Seasonal variation of secondary organic aerosol tracers in Central Tibetan Plateau
}

\author{
R.-Q. Shen ${ }^{1,3}$, X. Ding ${ }^{1}$, Q.-F. He ${ }^{1,3}$, Z.-Y. Cong ${ }^{2}$, Q.-Q. Yu ${ }^{1,3}$, and X.-M. Wang ${ }^{1}$ \\ ${ }^{1}$ State Key Laboratory of Organic Geochemistry, Guangzhou Institute of Geochemistry, Chinese Academy of Sciences, \\ Guangzhou 510640, China \\ ${ }^{2}$ Key Laboratory of Tibetan Environment Changes and Land Surface Processes, Institute of Tibetan Plateau Research, \\ Chinese Academy of Sciences, Beijing 100085, China \\ ${ }^{3}$ University of Chinese Academy of Sciences, Beijing, 100049, China
}

Correspondence to: X. Ding (xiangd@gig.ac.cn)

Received: 13 January 2015 - Published in Atmos. Chem. Phys. Discuss.: 10 March 2015

Revised: 8 July 2015 - Accepted: 1 August 2015 - Published: 10 August 2015

\begin{abstract}
Secondary organic aerosol (SOA) affects the earth's radiation balance and global climate. High-elevation areas are sensitive to global climate change. However, at present, SOA origins and seasonal variations are understudied in remote high-elevation areas. In this study, particulate samples were collected from July 2012 to July 2013 at the remote Nam Co (NC) site, Central Tibetan Plateau and analyzed for SOA tracers from biogenic (isoprene, monoterpenes and $\beta$-caryophyllene) and anthropogenic (aromatics) precursors. Among these compounds, isoprene $\mathrm{SOA}\left(\mathrm{SOA}_{\mathrm{I}}\right)$ tracers represented the majority $\left(26.6 \pm 44.2 \mathrm{ng} \mathrm{m}^{-3}\right)$, followed by monoterpene SOA $\left(\mathrm{SOA}_{\mathrm{M}}\right)$ tracers $\left(0.97 \pm 0.57 \mathrm{ng} \mathrm{m}^{-3}\right)$, aromatic SOA $\left(\mathrm{SOA}_{\mathrm{A}}\right)$ tracer (2,3-dihydroxy-4-oxopentanoic acid, DHOPA, $0.25 \pm 0.18 \mathrm{ng} \mathrm{m}^{-3}$ ) and $\beta$-caryophyllene SOA tracer $\left(\beta\right.$-caryophyllenic acid, $0.09 \pm 0.10 \mathrm{ng} \mathrm{m}^{-3}$ ). SOA tracers exhibited high concentrations in the summer and low levels in the winter. The similar temperature dependence of $\mathrm{SOA}_{\mathrm{I}}$ tracers and isoprene emission suggested that the seasonal variation of $\mathrm{SOA}_{I}$ tracers at the NC site was mainly influenced by the isoprene emission. The ratio of high- $\mathrm{NO}_{x}$ to low- $\mathrm{NO}_{x}$ products of $\mathrm{SOA}_{\mathrm{I}}$ (2-methylglyceric acid to 2methyltetrols) was highest in the winter and lowest in the summer, due to the influence of temperature and relative humidity. The seasonal variation of $\mathrm{SOA}_{\mathrm{M}}$ tracers was impacted by monoterpenes emission and gas-particle partitioning. During the summer to the fall, temperature effect on partitioning was the dominant process influencing $\mathrm{SOA}_{\mathrm{M}}$ tracers' variation; while the temperature effect on emission was
\end{abstract}

the dominant process influencing $\mathrm{SOA}_{M}$ tracers' variation during the winter to the spring. $\mathrm{SOA}_{\mathrm{M}}$ tracer levels did not elevate with increased temperature in the summer, probably resulting from the counteraction of temperature effects on emission and partitioning. The concentrations of DHOPA were 1-2 orders of magnitude lower than those reported in the urban regions of the world. Due to the transport of air pollutants from the adjacent Bangladesh and northeastern India, DHOPA presented relatively higher levels in the summer. In the winter when air masses mainly came from northwestern India, mass fractions of DHOPA in total tracers increased, although its concentrations declined. The SOAtracer method was applied to estimate secondary organic carbon (SOC) from these four precursors. The annual average of SOC was $0.22 \pm 0.29 \mu \mathrm{gC} \mathrm{m}^{-3}$, with the biogenic SOC (sum of isoprene, monoterpenes and $\beta$-caryophyllene) accounting for $75 \%$. In the summer, isoprene was the major precursor with its SOC contributions of $81 \%$. In the winter when the emission of biogenic precursors largely dropped, the contributions of aromatic SOC increased. Our study implies that anthropogenic pollutants emitted in the Indian subcontinent could be transported to the TP and have an impact on SOC over the remote NC. 


\section{Introduction}

Organic aerosol affects the earth's radiation balance and global climate. As a large fraction of organic aerosol, secondary organic aerosol (SOA) is produced by homogenous (Claeys et al., 2004) and heterogeneous (Jang et al., 2002) reactions of volatile organic compounds (VOCs) as well as aging of organic aerosol (Robinson et al., 2007; Donahue et al., 2012). The global emissions of biogenic VOCs (BVOCs), such as isoprene and monoterpenes (Guenther et al., 1995) were estimated to be one order of magnitude higher than those of anthropogenic sources (Piccot et al., 1992). Thus, global SOA is believed to be largely from BVOCs.

SOA tracers from specific VOCs can provide an insight into processes and sources influencing SOA formation and spatiotemporal distribution. The identification of the isoprene SOA $\left(\mathrm{SOA}_{\mathrm{I}}\right)$ tracers, 2-methyltetrols (Claeys et al., 2004) revealed the importance of $\mathrm{SOA}_{I}$ in global SOA burden. Further studies in high- $\mathrm{NO}_{x}$ and low- $\mathrm{NO}_{x}$ products of isoprene intermediates (e.g. methacrylic acid epoxide and isoprene epoxydiols) provided more details in the mechanisms of $\mathrm{SOA}_{\mathrm{I}}$ formation under the influence of $\mathrm{NO}_{x}$ (Paulot et al., 2009; Froyd et al., 2010; Surratt et al., 2010; Lin et al., 2013). The identification of tracers from aromatic SOA $\left(\mathrm{SOA}_{\mathrm{A}}\right)$ (Offenberg et al., 2007) offered a way to directly evaluate the variation of anthropogenic SOA, particularly in urban regions. In addition, specific tracers have been determined in monoterpene SOA ( $\mathrm{SOA}_{\mathrm{M}}$ ) (Jaoui et al., 2005; Claeys et al., 2007) and $\beta$-caryophyllene SOA (SOA $)$ (Jaoui et al., 2007; van Eijck et al., 2013). Based on these SOA tracers, Kleindienst and coworkers further developed an SOA tracer method to attribute SOA sources in the ambient air. Since it is difficult to directly measure SOA, the SOAtracer method provides a valuable technique to estimate SOA in the ambient air, and it has been widely used around the world (Hu et al., 2008; von Schneidemesser et al., 2009; Guo et al., 2012; Lewandowski et al., 2013; Ding et al., 2014).

High-elevation areas are sensitive to global climate change (Xua et al., 2009). Observation of aerosol concentrations and compositions at high-elevation sites can provide insight into the influence of natural and anthropogenic aerosols on global climate. The Tibetan Plateau (TP), the largest and highest plateau, is at the juncture of large desert areas and the densely populated Indian subcontinent. Previous studies found the northwesterly winds could bring dust from the western deserts to the TP and lead to high levels of geological aerosols at a site on the southeast TP (Zhao et al., 2013). Moreover, anthropogenic pollutants (e.g. sulfate, nitrate, potassium, element carbon, and heavy metals) emitted in the developing countries in South Asia could be transported to the TP by the southerly and southwesterly winds, especially during the summer monsoon season (Cong et al., 2007; Ming et al., 2010; Li et al., 2013; Zhao et al., 2013).

The observation at the remote central TP site, Nam Co (NC) discovered that the mean ratio of organic carbon (OC) to element carbon (EC) was $31.9 \pm 31.1$ during July 2006 to January 2007, implying the significant SOA contribution to OC (Ming et al., 2010) in the TP. However, there are only three studies in SOA compositions within the TP. Li et al. (2013) reported biogenic SOA (BSOA) tracers during the summer of 2010 at Qinghai Lake in the northeastern part of the TP. Stone et al. (2012) measured BSOA tracers from August to October 2005 on the south slope of Himalayas in the southwestern part of the TP. Due to the limited samples, it was difficult to examine the seasonal variation of these BSOA tracers in the TP. Moreover, due to the lack of anthropogenic SOA tracers, it was not possible to examine anthropogenic SOA in the TP, although above discussions have demonstrated that air pollutants from South Asia could be transported to the TP. Our recent study provided a snapshot of SOA tracers over China (including the NC and Linzhi sites in the TP) during the summer of 2012 (Ding et al., 2014). In this study, the observation at the remote NC site extended to 1 year. Seasonal trends of SOA tracers from isoprene, monoterpene, $\beta$-caryophyllene and aromatics were determined in the TP. Furthermore, secondary organic carbon (SOC) was estimated by the SOA-tracer method to check the variations of SOA origins at the NC site. To our knowledge, it is the first time that the seasonal trends of SOA tracers and origins are studied in the remote TP.

\section{Experiment}

\subsection{Field sampling}

Samples were collected at a remote site $(4730 \mathrm{~m}$ above sea level) at the southeastern shore of Nam Co Lake in the central TP (Fig. 1). Nam Co Lake $\left(90^{\circ} 16^{\prime}\right.$ to $91^{\circ} 03^{\prime} \mathrm{E}$ and $30^{\circ} 30^{\prime}$ to $30^{\circ} 55^{\prime} \mathrm{N}$ ) is located in the Nyainqen Tanglha Mountain Range with a total area of $2017 \mathrm{~km}^{2}$ (Zhou et al., 2013). The major vegetation in the Nam Co Lake Basin is the high cold alpine meadow.

Sampling was undertaken from July 2012 to July 2013. An Anderson sampler equipped with nine-stage cascade impactors and pre-baked quartz fiber filters (Whatman, baked at $450{ }^{\circ} \mathrm{C}$ for $8 \mathrm{~h}$ ) was used to get size-segregated particle samples at an air flow rate of $28.3 \mathrm{~L} \mathrm{~min}^{-1}$. The $50 \%$ cutoff sizes are <0.4, 0.4-0.7, 0.7-1.1, 1.1-2.1, 2.1-3.3, 3.3-4.7, $4.7-5.8,5.8-9.0$, and $\geq 9.0 \mu \mathrm{m}$, respectively. The flow rate was calibrated before and after each sampling episode using an airflow meter to ensure the sampler operated at the specified flow rate. One set of nine size-fractionated filters were collected for $72 \mathrm{~h}$ every 2 weeks. Additionally, four sets of field blanks were collected in the same way as the ambient samples for $5 \mathrm{~min}$ when the sampler was turned off. All samples were wrapped with aluminum foil and stored at $-18^{\circ} \mathrm{C}$ before analysis. 


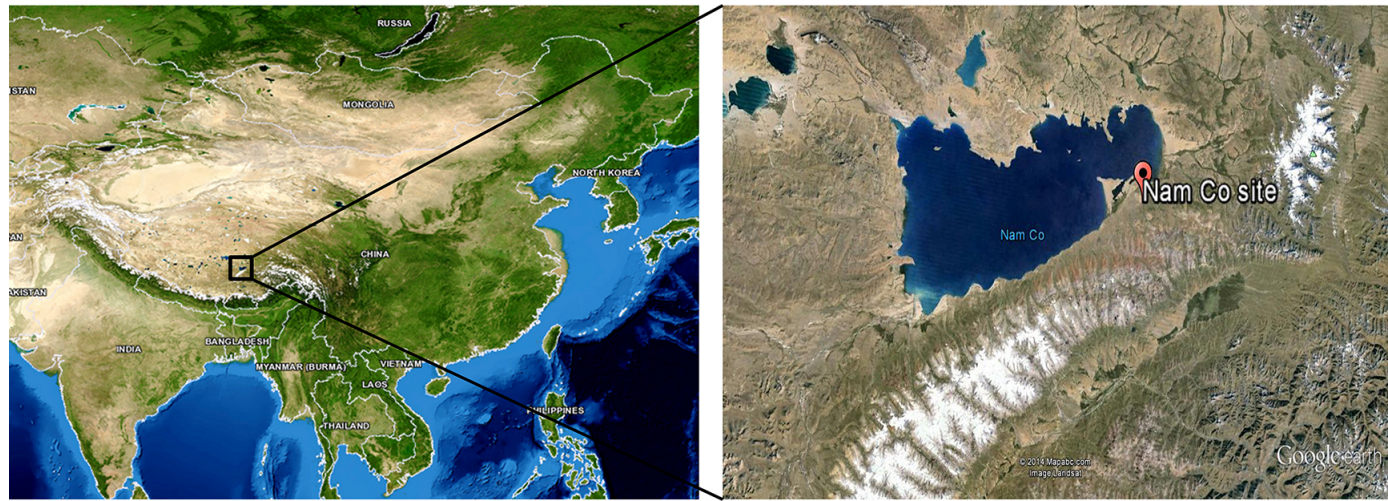

Figure 1. Nam Co site in the Tibetan Plateau, China.

\subsection{Chemical analysis}

Each set of nine filters were combined together as one sample to meet the analysis requirement. Detailed information on the SOA tracer analysis is described elsewhere (Ding et al., 2014). Prior to solvent extraction, isotope-labeled standard mixtures were spiked into samples as internal standards. Samples were extracted twice by sonication with the mixed solvent dichloride methane (DCM)/hexane $(1: 1, v / v)$, then three times with the mixed solvent DCM/methanol $(1: 1$, $v / v$ ). The extracts of each sample were combined, filtered and concentrated to $\sim 2 \mathrm{~mL}$. Then, the concentrated solution was divided into two parts for methylation and silylation, respectively.

The samples were analyzed by a gas chromatography/mass spectrometer detector (GC/MSD, Agilent 7890/5975C) in the selected ion monitoring (SIM) mode with a $30 \mathrm{~m}$ HP-5 MS capillary column (i.d. $0.25 \mathrm{~mm}$, $0.25 \mu \mathrm{m}$ film thickness). Splitless injection of a $2 \mu \mathrm{L}$ sample was performed. The $\mathrm{GC}$ temperature was initiated at $65^{\circ} \mathrm{C}$, held for $2 \mathrm{~min}$, then increased to $290^{\circ} \mathrm{C}$ at $5^{\circ} \mathrm{C} \mathrm{min}^{-1}$ and held for $20 \mathrm{~min}$. Thirteen SOA tracers were quantified by the GC/MSD coupled with an electron impact (EI) ionization source, including five $\mathrm{SOA}_{\mathrm{M}}$ tracers (cis-pinonic acid, pinic acid, 3-methyl-1,2,3-butanetricarboxylic acid, 3-hydroxyglutaric acid and 3-hydroxy-4,4-dimethylglutaric acid), six $\mathrm{SOA}_{\mathrm{I}}$ tracers (2-methylthreitol, 2-methylerythritol, 2-methylglyceric acid, cis-2-methyl-1,3,4-trihydroxy-1butene, trans-2-methyl-1,3,4-trihydroxy-1-butene and 3-methyl-2,3,4-trihydroxy-1-butene), one $\operatorname{SOA}_{C}$ tracer $(\beta$ caryophyllenic acid) and one $\mathrm{SOA}_{\mathrm{A}}$ tracer (2,3-dihydroxy4-oxopentanoic acid, DHOPA). Figure S1 in the Supplement presents the total ion chromatogram (TIC) of these SOA tracers. cis-Pinonic acid and pinic acid were quantified by authentic standards. Due to the lack of standards, the SOA tracers were quantified using erythritol (Claeys et al., 2004; Ding et al., 2008). The other $\mathrm{SOA}_{M}$ tracers were quantified using cis-pinonic acid. $\beta$-Caryophyllenic acid and DHOPA were quantified using octadecanoic acid and azelaic acid, respectively (Ding et al., 2012). The EI spectrum of each SOA tracer is shown in Figs. S2-S4. The method detection limits (MDLs) for cis-pinonic acid, pinic acid, erythritol, octadecanoic acid and azelaic acid were 0.03, 0.05, 0.04, 0.03 and $0.07 \mathrm{ng} \mathrm{m}^{-3}$, respectively, at a total volume of $122 \mathrm{~m}^{3}$.

\subsection{Quality assurance and quality control}

Field and laboratory blanks were analyzed in the same manner as the field samples. These SOA tracers were not detected in the field or laboratory blanks. To evaluate the recoveries of the analytical method, six spiked samples (authentic standards spiked into solvent with pre-baked quartz filters) were analyzed. The recoveries were $101 \pm 3 \%$ for $\mathrm{cis}$ pinonic acid, $70 \pm 10 \%$ for pinic acid, $65 \pm 14 \%$ for erythritol, $83 \pm 7 \%$ for octadecanoic acid, and $89 \pm 9 \%$ for azelaic acid. The relative differences for target compounds in samples collected in parallel $(n=6)$ were all below $15 \%$.

It should be noted that ketopinic acid was used as the surrogate for the quantification of all SOA tracers by Kleindienst et al. (2007); while different surrogates were used to quantify different SOA tracers in this study. The response factors of internal standard calibration for the five surrogates ranged from 0.98 (azelaic acid) to 1.78 (pinic acid), with the average of 1.38 and the relative standard deviation (RSD) of $23 \%$. The response factor of ketopinic acid was also calculated in this study. Its value (1.27) was consistent with the average of the five surrogates.

\subsection{Estimation of measurement uncertainty}

Since there is no commercial standard available for most SOA tracers (except cis-pinonic acid and pinic acid), the use of surrogate standards for quantification introduces additional error to measurement. Error in analyte measurement $\left(E_{\mathrm{A}}\right)$ is propagated from the standard deviation of the field blank $\left(E_{\mathrm{FB}}\right)$, error in spike recovery $\left(E_{\mathrm{R}}\right)$ and the error from 
surrogate quantification $\left(E_{\mathrm{Q}}\right)$ :

$E_{\mathrm{A}}=\sqrt{E_{\mathrm{FB}}^{2}+E_{\mathrm{R}}^{2}+E_{\mathrm{Q}}^{2}}$.

Since SOA tracers were not detected in the field blanks, $E_{\mathrm{FB}}$ was 0 in this study. The spike recoveries of surrogate standards were used to estimate the $E_{\mathrm{R}}$ of tracers which ranged from $1 \%$ (cis-pinonic acid) to $35 \%$ (erythritol). Stone et al. (2012) developed an empirical approach to estimate $E_{\mathrm{Q}}$ based on homologous series of atmospherically relevant compounds. The relative error introduced by each carbon atom $\left(E_{n}\right)$ was estimated to be $15 \%$, each oxygenated functional group $\left(E_{f}\right)$ to be $10 \%$ and alkenes $\left(E_{d}\right)$ to be $60 \%$. The errors introduced from surrogate quantification are treated as additive and are calculated as

$E_{\mathrm{Q}}=E_{n} \Delta n+E_{f} \Delta f+E_{d} \Delta d$,

where $\Delta n$ is the difference in carbon atom number between a surrogate and an analyte, $\Delta f$ is the difference in oxygencontaining functional group between a surrogate and an analyte, $\Delta d$ is the difference in alkene functionality between a surrogate and an analyte.

Table S1 shows the estimated uncertainties in tracer measurement. The errors from surrogate quantification $\left(E_{\mathrm{Q}}\right)$ ranged from $15 \%$ (2-methyltetrols) to $155 \%(\beta$ caryophyllenic acid) in this study. Propagated with the error in recovery, the uncertainties in analyte measurement $\left(E_{\mathrm{A}}\right)$ were estimated in the range of 38 to $156 \%$.

\subsection{Backward trajectories}

The air masses' transport during each sampling episode was investigated using Hybrid Single Particle Lagrangian Integrated Trajectory Model (HYSPLIT V4.9). Five-day backward trajectories (BTs) were analyzed during each sampling episode with $6 \mathrm{~h}$ step at the height of $500 \mathrm{~m}$ above ground level. Cluster analysis was then performed to present the mean trajectory of each cluster, based on all the trajectories during our campaign.

\section{Results and discussions}

\subsection{Seasonal variations of SOA tracers}

Since the NC site is located in the high-elevation TP, the annual temperature was only $-1.64{ }^{\circ} \mathrm{C}$ with the range of $-16.1^{\circ} \mathrm{C}$ in January to $10.2^{\circ} \mathrm{C}$ in July (Table 1 ). The annual relative humidity ( $\mathrm{RH}$ ) was $58 \%$ with the peak in July $(84 \%)$ and the lowest in January $(30 \%)$. The sum of all tracers ranged from 0.78 to $185 \mathrm{ng} \mathrm{m}^{-3}$. Among these compounds, $\mathrm{SOA}_{\mathrm{I}}$ tracers $\left(26.6 \pm 44.2 \mathrm{ng} \mathrm{m}^{-3}\right)$ represented the majority, followed by $\mathrm{SOA}_{M}$ tracers $\left(0.97 \pm 0.57 \mathrm{ng} \mathrm{m}^{-3}\right)$, DHOPA $\left(0.25 \pm 0.18 \mathrm{ng} \mathrm{m}^{-3}\right)$ and $\beta$-caryophyllenic acid $\left(0.09 \pm 0.10 \mathrm{ng} \mathrm{m}^{-3}\right)$. During the summer (July-September
2012 and June-July 2013), SOA I tracers presented the majority $(>95 \%)$. The mass fractions of $\mathrm{SOA}_{M}$ tracers in all compounds increased during the cold period (October 2012 to May 2013).

\subsubsection{Isoprene SOA tracers}

The total concentrations of $\mathrm{SOA}_{\mathrm{I}}$ tracers (sum of six tracers) ranged from $0.36-184 \mathrm{ng} \mathrm{m}^{-3}$. The levels of SOA tracers were 1-2 orders of magnitude higher than those over the global oceans and the Arctic (Table 2). Among the $\mathrm{SOA}_{\mathrm{I}}$ traces, 2-methyltetrols (sum of 2-methylthreitol and 2-methylerythritol, MTLs) were the major components $(72 \%)$, with an annual average of $23.8 \pm 40.3 \mathrm{ng} \mathrm{m}^{-3}$ ( 0.18 to $165 \mathrm{ng} \mathrm{m}^{-3}$ ). The 2-methylglyceric acid (MGA) averaged $1.95 \pm 2.92 \mathrm{ng} \mathrm{m}^{-3}$ and $C_{5}$-alkenetriols (sum of cis-2-methyl-1,3,4-trihydroxy-1-butene, trans-2-methyl1,3,4-trihydroxy-1-butene, and 3-methyl-2,3,4-trihydroxy-1butene) averaged $0.93 \pm 1.39 \mathrm{ng} \mathrm{m}^{-3}$. MTLs are produced through the particle-phase uptake of the epoxydiols that formed in the gas-phase photo-oxidation of isoprene under low- $\mathrm{NO}_{x}$ or $\mathrm{NO}_{x}$ free conditions (Paulot et al., 2009; Surratt et al., 2010). Since the remote TP is a low- $\mathrm{NO}_{x}$ environment, it is expected that the low- $\mathrm{NO}_{x}$ products, MTLs dominated over other SOA I tracers. The majority of MTLs at the NC site was consistent with those observed within the TP (Stone et al., 2012; Li et al., 2013) and over most global oceans (Fu et al., 2011; Hu et al., 2013), but different from those over the North Pacific Ocean and the Arctic where MGA was the major $\mathrm{SOA}_{\mathrm{I}}$ tracer due to the significant influence of Siberian fires (Fu et al., 2011; Ding et al., 2013). The two MTL isomers exhibited a strong correlation with each other throughout the year $\left(R^{2}=0.996, p<0.001\right)$ with a slope of 3.7 , indicating that the two isomers shared similar formation pathways.

Figure 2 a presents a typical seasonal trend of $\mathrm{SOA}_{I}$ tracers that high concentrations all existed in the summer. From October 2012 to April 2013, temperature was below zero, the levels of $\mathrm{SOA}_{\mathrm{I}}$ tracers dramatically decreased as low as $0.38 \mathrm{ng} \mathrm{m}^{-3}$ in January.

Isoprene emission rate $\left(E_{\mathrm{I}}\right)$ depends on light and temperature (Guenther et al., 1993):

$E_{\mathrm{I}}=\mathrm{EF}_{\mathrm{I}} \times C_{\mathrm{L}} \times C_{T}$,

where $\mathrm{EF}_{\mathrm{I}}$ is the basal emission rate at $30^{\circ} \mathrm{C}$ leaf temperature and $1000 \mu \mathrm{mol} \mathrm{m}^{-2} \mathrm{~s}^{-1}$ PAR. $C_{\mathrm{L}}$ and $C_{T}$ are the factors representing the influences of light and temperature, respectively. $C_{T}$ can be estimated as

$C_{T}=\frac{\exp ^{\frac{C_{T 1}\left(T-T_{\mathrm{s}}\right)}{\mathrm{RT}_{\mathrm{s}} T}}}{1+\exp ^{\frac{C_{T 2}\left(T-T_{m}\right)}{\mathrm{RT}_{\mathrm{s}} T}}}$.

Then the natural logarithm of $C_{T}$ is calculated as

$\mathrm{LnC}_{T}=\frac{C_{T 1}}{\mathrm{RT}_{\mathrm{S}}}\left(1-\frac{T_{\mathrm{s}}}{T}\right)-\operatorname{Ln}\left[1+\exp ^{\frac{\mathrm{C}_{T 2}}{\mathrm{RT}_{\mathrm{s}}}\left(1-\frac{T_{m}}{T}\right)}\right]$, 
Table 1. SOA tracers at the NC site $\left(\mathrm{ng} \mathrm{m}^{-3}\right)$.

\begin{tabular}{|c|c|c|c|c|c|c|c|}
\hline \multirow[t]{2}{*}{ Month } & \multirow{2}{*}{$\begin{array}{l}\text { Temp. } \\
{ }^{\circ} \mathrm{C}^{\mathrm{a}}\end{array}$} & \multirow{2}{*}{$\begin{array}{l}\text { RH } \\
\%^{\mathrm{a}}\end{array}$} & \multicolumn{5}{|c|}{ SOA tracers } \\
\hline & & & Isoprene & Monoterpenes & $\beta$-Caryophyllene & Aromatics & Sum \\
\hline Jul 2012 & 7.78 & 84 & $54.1 \pm 22.9^{b}$ & $0.45 \pm 0.48$ & $0.10 \pm 0.13$ & $0.37 \pm 0.23$ & $55.0 \pm 22.5$ \\
\hline Aug 2012 & 7.70 & 76 & $66.0 \pm 69.3$ & $0.46 \pm 0.18$ & $n d^{\mathrm{c}}$ & $0.49 \pm 0.03$ & $67.0 \pm 69.1$ \\
\hline Sep 2012 & 5.92 & 66 & $100 \pm 118$ & $1.06 \pm 0.43$ & $0.08 \pm 0.11$ & $0.35 \pm 0.36$ & $102 \pm 118$ \\
\hline Oct. 2012 & -1.50 & 70 & $14.7 \pm 19.0$ & $1.79 \pm 0.08$ & $0.16 \pm 0.01$ & $0.22 \pm 0.07$ & $16.8 \pm 18.9$ \\
\hline Nov 2012 & -14.9 & 63 & $2.04 \pm 1.76$ & $1.99 \pm 0.56$ & $0.20 \pm 0.19$ & $0.25 \pm 0.15$ & $4.48 \pm 2.66$ \\
\hline Dec 2012 & -13.0 & 45 & 0.52 & 0.73 & nd & nd & 1.25 \\
\hline Jan 2013 & -16.1 & 30 & $0.38 \pm 0.02$ & $0.30 \pm 0.04$ & $0.03 \pm 0.01$ & $0.08 \pm 0.01$ & $0.78 \pm 0.01$ \\
\hline Feb 2013 & -9.69 & 49 & $0.86 \pm 0.45$ & $0.52 \pm 0.25$ & $0.09 \pm 0.02$ & $0.09 \pm 0.01$ & $1.55 \pm 0.22$ \\
\hline Mar 2013 & -7.83 & 41 & $1.56 \pm 1.15$ & $0.74 \pm 0.59$ & $0.23 \pm 0.25$ & $0.12 \pm 0.17$ & $2.65 \pm 2.15$ \\
\hline Apr 2013 & -3.42 & 52 & $2.82 \pm 0.20$ & $1.24 \pm 0.15$ & $0.15 \pm 0.03$ & $0.20 \pm 0.03$ & $4.40 \pm 0.11$ \\
\hline May 2013 & 3.77 & 54 & $10.1 \pm 9.70$ & $1.11 \pm 0.13$ & $0.06 \pm 0.06$ & $0.27 \pm 0.19$ & $11.5 \pm 9.97$ \\
\hline Jun 2013 & 7.25 & 55 & $54.1 \pm 42.9$ & $0.83 \pm 0.18$ & $0.03 \pm 0.04$ & $0.30 \pm 0.02$ & $55.3 \pm 42.8$ \\
\hline Jul 2013 & 10.2 & 69 & 41.9 & 1.41 & 0.07 & 0.49 & 43.9 \\
\hline Annual & -1.64 & 58 & $26.6 \pm 44.2$ & $0.97 \pm 0.57$ & $0.09 \pm 0.10$ & $0.25 \pm 0.18$ & $28.0 \pm 44.2$ \\
\hline
\end{tabular}

${ }^{a}$ Temperature and RH are monthly averages; ${ }^{\mathrm{b}}$ one standard deviation; c "nd" means not detected.

Table 2. SOA tracers in remote places on the global range $\left(\mathrm{ng} \mathrm{m}^{-3}\right)$.

\begin{tabular}{|c|c|c|c|c|c|c|c|}
\hline \multicolumn{2}{|r|}{ Locations } & \multirow[t]{2}{*}{ Seasons } & \multirow[t]{2}{*}{ References } & \multicolumn{4}{|c|}{ SOA tracers } \\
\hline & & & & Isoprene $^{\mathrm{a}}$ & Monoterpenes $^{\mathrm{a}}$ & $\beta$-Caryophyllene & Aromatics \\
\hline \multirow[t]{3}{*}{ Tibetan Plateau } & Nam Co Lake & Whole year & This study & $26.6(0.36-184)^{\mathrm{b}}$ & $0.97(0.11-2.39)$ & 0.09 (nd-0.40) & $0.25(\mathrm{nd}-0.61)$ \\
\hline & Qianghai Lake & Summer & Li et al. (2013) & $2.50(0.13-7.15)$ & $2.95(0.30-10.4)$ & $0.87(0.05-2.41)$ & $\mathrm{NA}^{\mathrm{c}}$ \\
\hline & Himalayas & Summer-autumn & Stone et al. (2012) & $30.7(5.5-105)$ & $13.2(5.6-31.3)$ & $1.6(1.1-2.3)$ & NA \\
\hline Arctic & Alert & Winter-Summer & Fu et al. (2009) & $0.3(0.08-0.567)$ & $1.6(0.138-5.3)$ & $0.12(0.01-0.372)$ & NA \\
\hline \multirow[t]{4}{*}{ Global oceans } & Arctic Ocean & Summer & Fu et al. (2013) & $4.0(0.16-31.8)$ & $4.8(0.44-24.1)$ & $0.017(0.005-0.048)$ & NA \\
\hline & Low- to mid-latitude & Fall-Spring & Fu et al. (2011) & $3.6(0.11-22)$ & $2.7(0.02-15)$ & $0.32(0-2.5)$ & NA \\
\hline & Antarctic to Arctic & Summer & Hu et al. (2013) & $8.5(0.018-36)$ & $3.0(0.05-20)$ & NA & NA \\
\hline & North Pacific and Arctic & Summer & Ding et al. (2013) & $0.62(0.12-1.45)$ & $0.06(0.01-0.25)$ & $0.002(\mathrm{nd}-0.03)$ & $\mathrm{nd}^{\mathrm{d}}$ \\
\hline
\end{tabular}

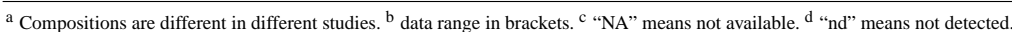

where $R=8.314 \quad \mathrm{~J} \quad \mathrm{~K}^{-1} \mathrm{~mol}^{-1}, \quad C_{T 1}=95000 \mathrm{~J} \mathrm{~mol}^{-1}$, $C_{T 2}=230000 \mathrm{~J} \mathrm{~mol}^{-1}, T_{\mathrm{s}}=303 \mathrm{~K}, T_{m}=314 \mathrm{~K}$, and $T$ is the leaf temperature (Guenther et al., 1993). Under the condition of $T<T_{m}$, the latter part in Eq. (5) is close to zero, and Ln $C_{T}$ is linearly correlated with $1 / T$.

Figure $3 \mathrm{a}$ presents a negative correlation between the natural logarithm of $\mathrm{SOA}_{\mathrm{I}}$ tracer levels and the reciprocal of temperature in Kelvin $(p<0.001)$. Moreover, the temperature dependence of $\mathrm{SOA}_{\mathrm{I}}$ tracers was similar to that of $C_{T}$, and $\mathrm{SOA}_{I}$ tracers exhibited a significant positive correlation with $C_{T}$ during our sampling at the NC site (Fig. 3b). These results indicated that the seasonal variation of $\mathrm{SOA}_{\mathrm{I}}$ tracers at the $\mathrm{NC}$ site was mainly influenced by the isoprene emission. Considering the short lifetime (several hours) of isoprene in the air, $\mathrm{SOA}_{\mathrm{I}}$ should be mainly formed from local precursor. In summer, high temperature and intense light could enhance isoprene emission and photo-reactions. Moreover, high temperature in summer could enhance the heterogeneous reactions of isoprene-derived epoxides on particles which play key roles in SOA formation (Lin et al., 2013; Paulot et al., 2009). All of these interpreted the high levels of $\mathrm{SOA}_{I}$ tracers in the summer at the $\mathrm{NC}$ site. In the winter, isoprene emission significantly dropped due to the extremely low temperature. Thus, the tracers were only in trace amount at the NC site.

It is worth noting that the ratio of MGA to MTLs (MGA/MTLs) was negatively correlated with temperature (Fig. 4a) and RH (Fig. 4b). Based on chamber results, the formation mechanisms of MGA and MTLs are quite different. MGA is produced under high- $\mathrm{NO}_{x}$ conditions, while MTLs are mainly formed under low- $\mathrm{NO}_{x}$ or $\mathrm{NO}_{x}$-free conditions (Surratt et al., 2010). Moreover, low RH (15-40\%) could enhance the formation of MGA in the particulate phase but not of MTLs (Zhang et al., 2011). In addition, high particle acidity would favor the formation of MTLs instead of MGA (Surratt et al., 2007). Although there are few data available in the $\mathrm{TP}$, the aerosols are expected to be neutral at the remote $\mathrm{NC}$ site. Thus, the influence of acidity on MGA/MTLs should not be significant. Isoprene emission is apparently high in summer due to high temperature and light intensity, which could enhance the ratio of isoprene to $\mathrm{NO}_{x}$ and favor MTLs formation at the $\mathrm{NC}$ site. Moreover, high RH $(\sim 70 \%)$ in the summer (Table 1) could not favor MGA formation. Thus, 


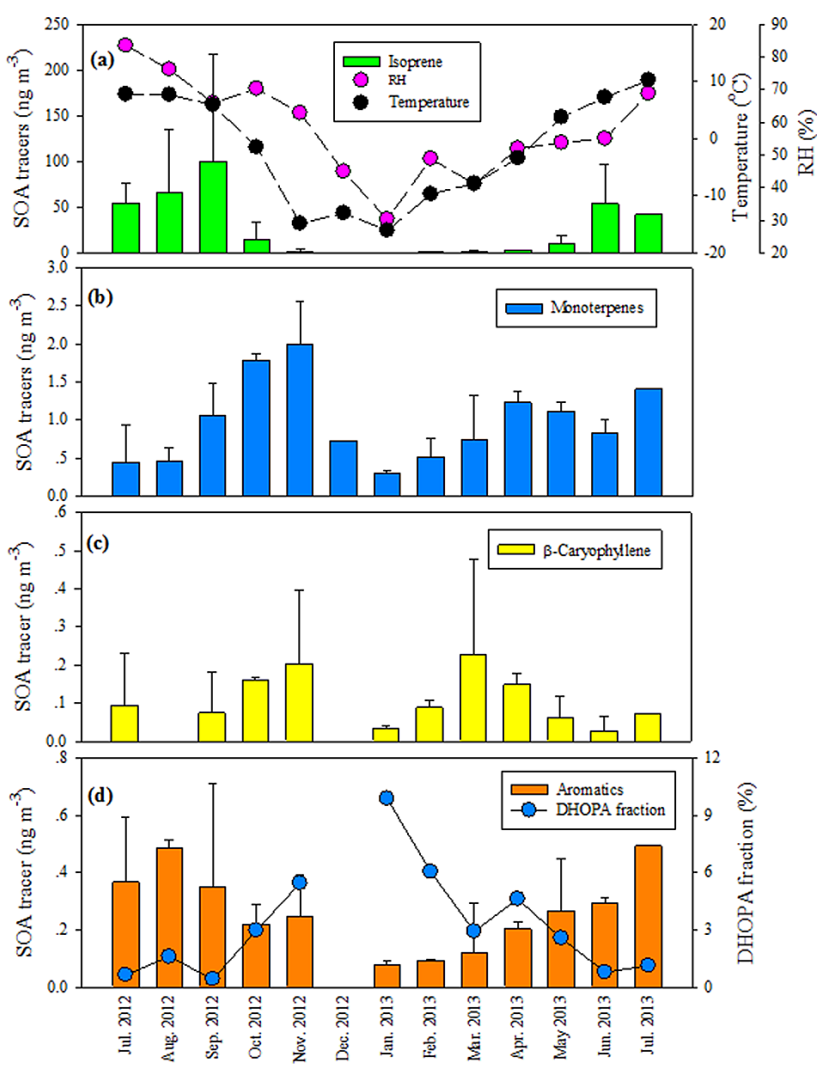

Figure 2. Monthly variations of SOA tracers.

MGA/MTLs exhibited the lowest values (less than 0.1) in the summer samples (Fig. 4). In the winter, both temperature and $\mathrm{RH}$ dropped to the lowest of the whole year. Low temperature reduced isoprene emission and low RH favored MGA formation. Thus, MGA/MTLs increased up to 0.8 in the winter samples (Fig. 4).

\subsubsection{Terpene SOA tracers}

The total concentrations of $\mathrm{SOA}_{M}$ tracers (sum of five tracers) ranged from $0.11-2.39 \mathrm{ng} \mathrm{m}^{-3}$. The levels of the $\mathrm{SOA}_{\mathrm{M}}$ tracers were consistent with those over the global oceans and the Arctic (Table 2). Among these traces, cis-pinonic acid was the major compound $(54 \%)$, with an annual average of $0.49 \pm 0.38 \mathrm{ng} \mathrm{m}^{-3}$, followed by pinic acid $\left(0.22 \pm 0.32 \mathrm{ng} \mathrm{m}^{-3}\right)$, 3-methyl1,2,3-butanetricarboxylic acid $\left(0.18 \pm 0.25 \mathrm{ng} \mathrm{m}^{-3}\right)$, 3-hydroxyglutaric acid $\left(0.08 \pm 0.06 \mathrm{ng} \mathrm{m}^{-3}\right)$ and 3-hydroxy4,4-dimethylglutaric acid (below MDL in the most samples).

The monthly variation of $\mathrm{SOA}_{\mathrm{M}}$ tracers did not fully follow that of temperature (Fig. 2b). From July to November 2012 (period 1), temperature decreased to $-15^{\circ} \mathrm{C}$; while $\mathrm{SOA}_{\mathrm{M}}$ tracer levels increased as high as $1.99 \mathrm{ng} \mathrm{m}^{-3}$. After that, both temperature and $\mathrm{SOA}_{\mathrm{M}}$ tracers dropped to the lowest values in January 2013, and increased concurrently until April 2013 (period 2). During May to July 2013 (period 3),
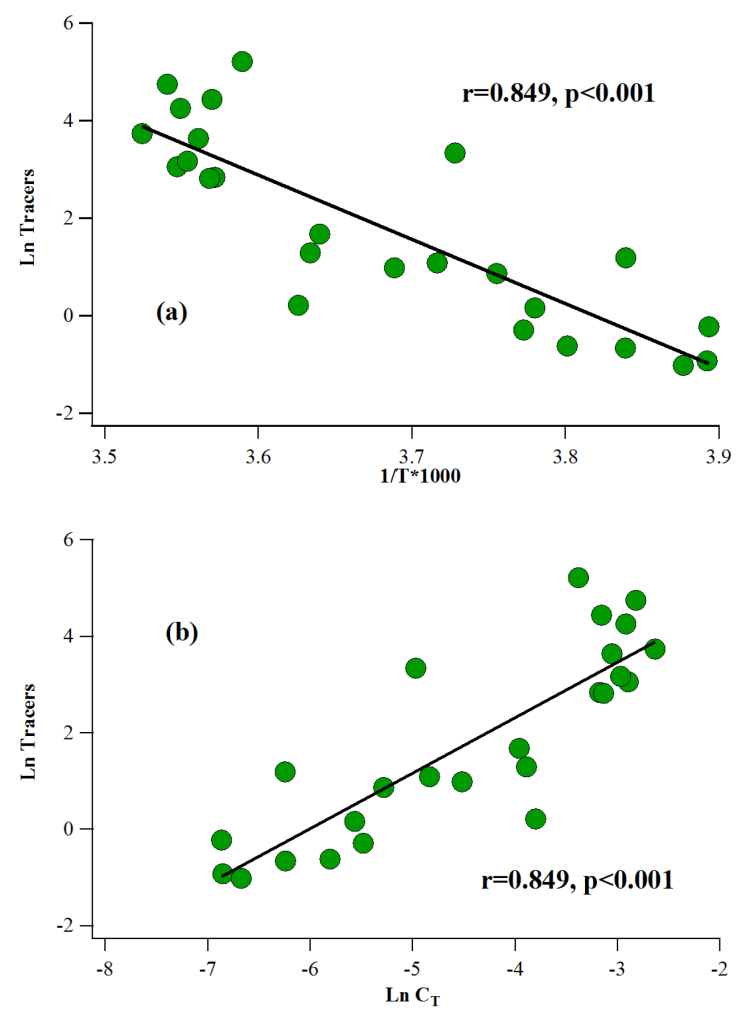

Figure 3. Correlations of $\mathrm{SOA}_{I}$ tracers with temperature (a) and $C_{T}$ (b).

$\mathrm{SOA}_{\mathrm{M}}$ tracer levels exhibited slight variation, although the temperature kept increasing.

The seasonal variation of $\mathrm{SOA}_{\mathrm{M}}$ tracers could be influenced by monoterpenes emission and gas-particle partitioning. Monoterpenes emission rate $\left(E_{\mathrm{M}}\right)$ is often assumed to be solely dependent on temperature (Guenther et al., 1993):

$E_{\mathrm{M}}=\mathrm{EF}_{\mathrm{M}} \times \gamma_{T}$
$\gamma_{T}=\exp ^{\beta\left(T-T_{\mathrm{s}}\right)}$

where $\mathrm{EF}_{\mathrm{M}}$ is monoterpenes emission rate at a standard temperature $T_{\mathrm{S}}(303 \mathrm{~K}), \gamma_{T}$ is the activity factor by temperature, $\beta$ is an empirical coefficient usually taken to be $0.09 \mathrm{~K}^{-1}$ (Guenther et al., 1993), $\mathrm{T}$ is the leaf temperature.

SOA yield $(Y)$ of precursors could be expressed using an empirical relationship based on gas-particle partitioning of two semi-volatile products (Odum et al., 1996):

$Y=M_{0} \sum_{i}^{2} \frac{\alpha_{i} K_{i}}{1+M_{0} K_{i}}$

where $M_{0}\left(\mu \mathrm{g} \mathrm{m}^{-3}\right)$ is the total concentration of absorbing organic material, $\alpha_{i}$ is the mass stoichiometric coefficients of the product $i, K_{i}\left(\mathrm{~m}^{3} \mu \mathrm{g}^{-1}\right)$ is the temperature-dependent partitioning coefficient of the semi-volatile compound $i$. Assuming a constant activity coefficient and mean molecular 

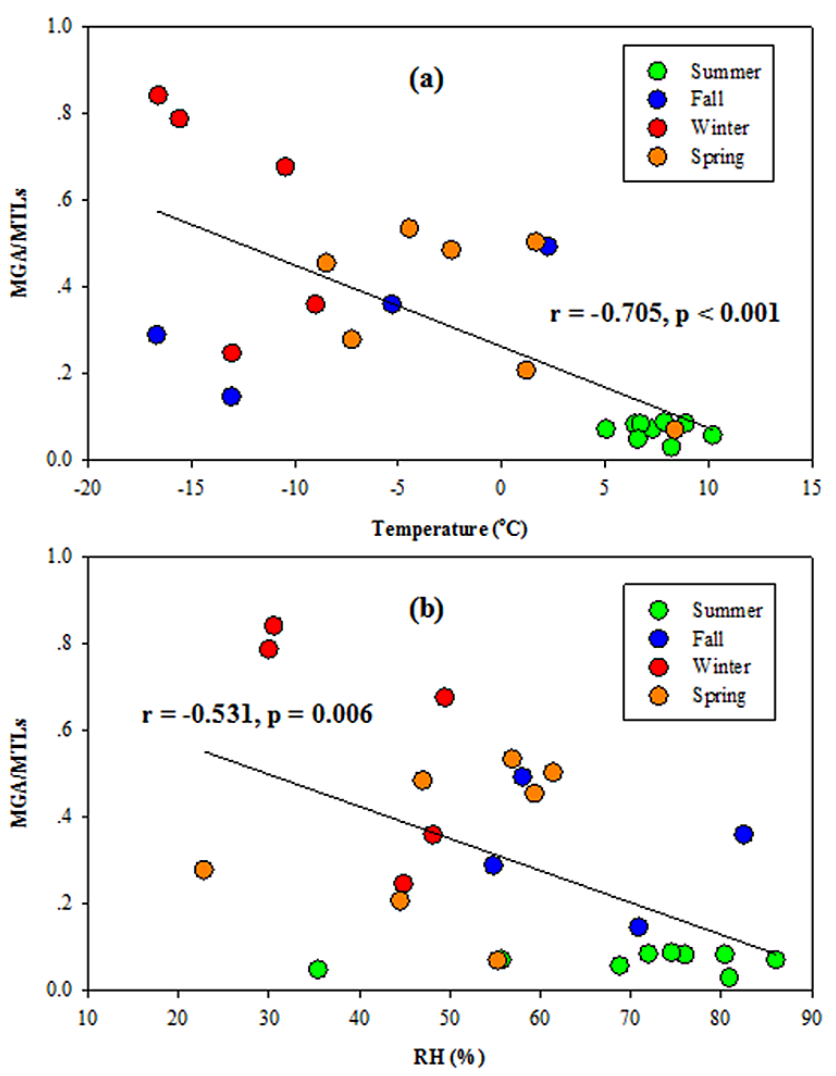

Figure 4. Correlations of MGA/MTL with temperature (a) and relative humidity (b). Summer is from July to September 2012 and from June to July 2013, fall is from October to November 2012, winter is from December 2012 to February 2013, and spring is from March to May 2013.

weight, the partitioning coefficient, $K_{i}(T)$ at a certain temperature $(T)$ could be estimated as (Sheehan and Bowman, 2001)

$K_{i}(T)=K_{i}^{*} \frac{T}{T^{*}} \exp \left[\frac{H_{i}}{R}\left(\frac{1}{T}-\frac{1}{T^{*}}\right)\right]$,

where $K_{i}^{*}$ is an experimentally determined partitioning coefficient at a reference temperature, $T^{*} . H_{i}$ is the vaporization enthalpy, $R$ is the gas constant. To model the temperaturedependent absorptive partitioning, three parameters, $\alpha_{i}, K_{i}$, and $H_{i}$, are required for each condensable product.

Table S2 lists all the parameters for two-product model of $\alpha$-pinene SOA which were also used to estimate the temperature effect on SOA partitioning by Sheehan and Bowman (2001). The available data of OC at the NC site were reported in the range of 1.18 to $2.26 \mu \mathrm{gC} \mathrm{m}^{-3}$ during July 2006 to January 2007 with an average of $1.66 \mu \mathrm{gC} \mathrm{m}{ }^{-3}$ (Ming et al., 2010). Thus, $\mathrm{M}_{0}$ is calculated as $2.32 \mu \mathrm{g} \mathrm{m}^{-3}$ by the average OC multiplying 1.4. Figure S5 shows the temperature dependence of $\alpha$-pinene emission rate $\left(\gamma_{T}\right)$ and SOA yield within the temperature range at the $\mathrm{NC}$ site $(-16.7$ to $10.2^{\circ} \mathrm{C}$ ). Obviously, decreasing temperature could reduce
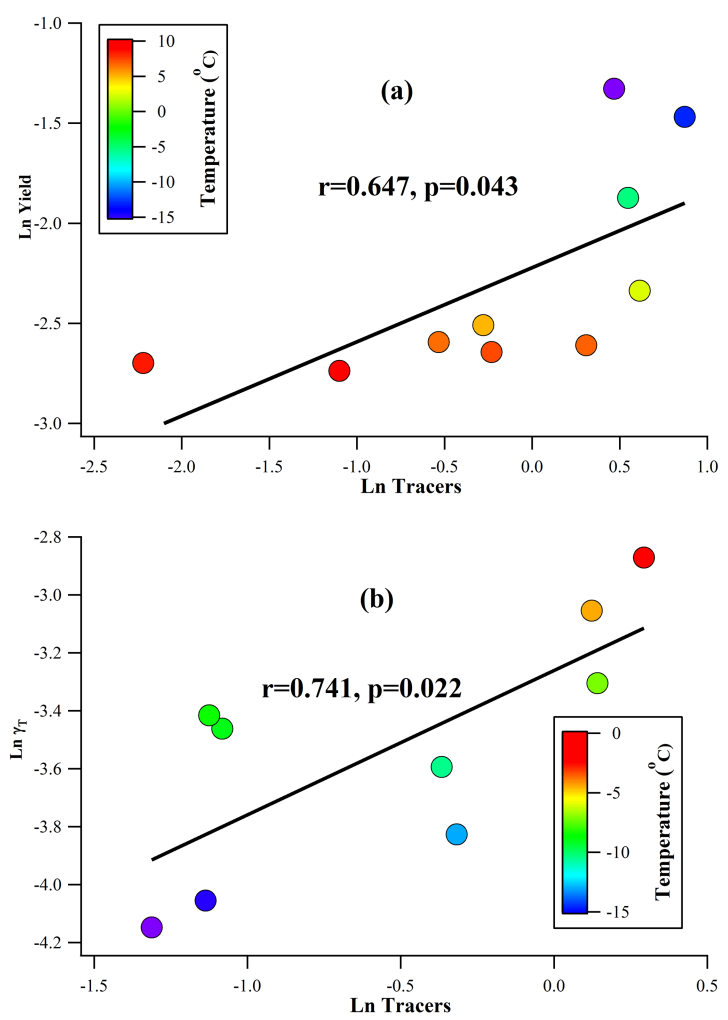

Figure 5. Correlation of $\mathrm{SOA}_{\mathrm{M}}$ tracers with $\mathrm{SOA}$ yield in period 1 (a) and $\gamma_{T}$ in period 2 (b).

the emission but enhance the gas to particle partitioning and SOA yield.

From July to November 2012 (period 1), high values of $\mathrm{SOA}_{\mathrm{M}}$ tracers and SOA yield existed under low temperature, and $\mathrm{SOA}_{M}$ tracers were positively correlated with SOA yield $(r=0.647, p<0.05$, Fig. 5a). These suggested that the temperature effect on partitioning was the dominant process influencing $\mathrm{SOA}_{\mathrm{M}}$ tracers' variation during the period 1. From December 2012 to April 2013 (period 2), high values of $\mathrm{SOA}_{\mathrm{M}}$ tracers and activity factor $\left(\gamma_{T}\right)$ existed under high temperature, and $\mathrm{SOA}_{\mathrm{M}}$ tracers were positively correlated with $\gamma_{T}(r=0.741, p<0.05$, Fig. 5b). These suggested that the temperature effect on emission was the dominant process influencing $\mathrm{SOA}_{\mathrm{M}}$ tracers' variation during the period 2. The increase of $\mathrm{SOA}_{M}$ tracer concentrations during spring was also observed in the southeastern United States (Ding et al., 2008), resulting from the enhancement of monoterpenes emission in spring (Kim, 2001). From May to July 2013 (period 3), $\mathrm{SOA}_{M}$ tracer concentrations were relative stable, and there was no correlation of $\mathrm{SOA}_{\mathrm{M}}$ tracers with $\gamma_{T}$ or SOA yield $(p>0.05)$. These might result from the counteraction of temperature effects on emission and partitioning during the summer.

Previous study proposed that cis-pinonic acid and pinic acid $(\mathrm{P})$ were the first-generation products of $\mathrm{SOA}_{\mathrm{M}}$ and only formed under low- $\mathrm{NO}_{x}$ conditions (Eddingsaas et al., 


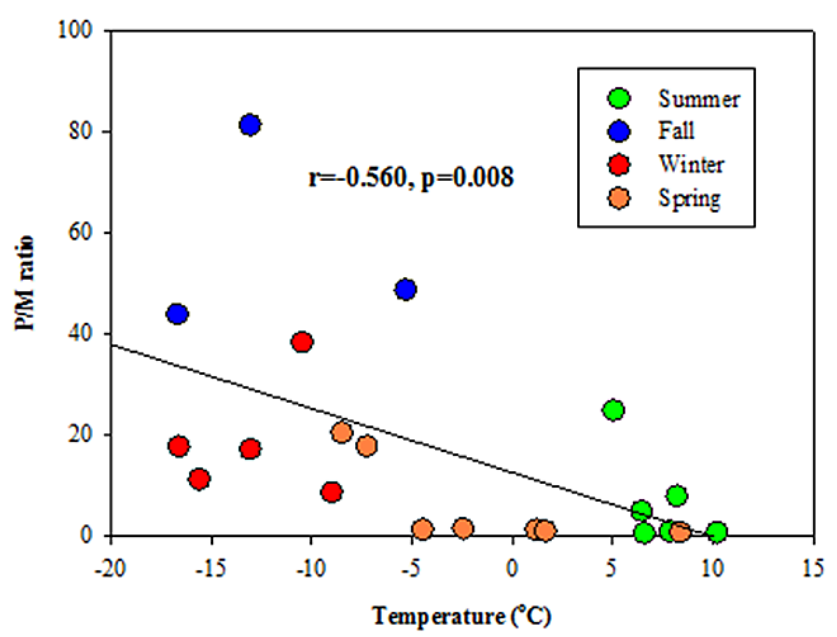

Figure 6. Negative correlation between $\mathrm{P}$ / M ratio and temperature.

2012). The dominance of cis-pinonic acid and pinic acid among $\mathrm{SOA}_{M}$ tracers at the remote $\mathrm{NC}$ site indicated that $\mathrm{SOA}_{\mathrm{M}}$ there was mainly formed under low- $\mathrm{NO}_{x}$ conditions. Moreover, cis-pinonic acid and pinic acid could be further photo-degraded to high-generation products, e.g. 3methyl-1,2,3-butanetricarboxylic acid (M) (Glasius et al., 2000; Jaoui et al., 2005; Szmigielski et al., 2007). And the ratio of cis-pinonic acid plus pinic acid to 3-methyl-1,2,3butanetricarboxylic acid $(\mathrm{P} / \mathrm{M})$ could be applied to trace the aging of $\mathrm{SOA}_{\mathrm{M}}$ (Ding et al., 2011; Gómez-González et al., 2012). In the fresh chamber-produced $\alpha$-pinene SOA samples, the ratios of $\mathrm{P} / \mathrm{M}$ were reported in the range of 1.51 to 3.21 (Offenberg et al., 2007). In this study, the ratio of P/M averaged $16.7 \pm 20.9$. Thus, $\mathrm{SOA}_{\mathrm{M}}$ was generally fresh at the NC site and should be mainly formed from local precursors. Figure 6 presents a negative correlation between $\mathrm{P} / \mathrm{M}$ and temperature $(r=-0.560, p=0.008)$. Higher $\mathrm{P} / \mathrm{M}$ ratios were observed in the fall and the winter, and lower P/M ratios occurred in the spring and the summer. Since temperature has positive influence on photo-reaction rates, the higher temperature during the summer could accelerate the photochemistry in the air and result in $\mathrm{P}$ to $\mathrm{M}$ conversion being more efficient. Thus, $\mathrm{SOA}_{\mathrm{M}}$ in the summer was more aged than that in the winter.

The levels of $\mathrm{SOA}_{\mathrm{C}}$ tracer, $\beta$-caryophyllenic acid were in the range of below MDL to $0.40 \mathrm{ng} \mathrm{m}^{-3}$. As Fig. 2c shows, the levels elevated from July to November 2012 and dropped to below MDL in December 2012. Then, the concentrations increased from January to March 2013 and decreased from April to June 2013. $\beta$-Caryophyllenic acid was positively correlated with $\mathrm{SOA}_{\mathrm{M}}$ tracers $(p=0.025)$, indicating that the seasonal variation of $\beta$-caryophyllenic acid was similar with that of the $\mathrm{SOA}_{M}$ tracers.

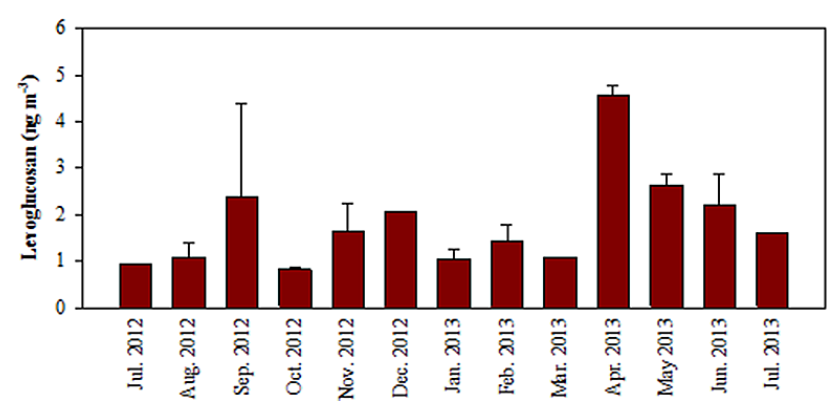

Figure 7. Monthly variation of biomass burning tracer, levoglucosan.

\subsubsection{Aromatic SOA tracer}

The levels of $\mathrm{SOA}_{\mathrm{A}}$ tracer, DHOPA were in the range of below MDL to $0.61 \mathrm{ng} \mathrm{m}^{-3}$. This anthropogenic tracer was not detected or reported in global remote areas (Table 2). Due to little human activity at the remote NC site, the highest concentration of DHOPA was 1-2 orders of magnitude lower than those (up to $52 \mathrm{ng} \mathrm{m}^{-3}$ ) reported in the urban regions of the United States (Lewandowski et al., 2013) and China (Ding et al., 2014). DHOPA exhibited the higher concentrations in the summer and the lower levels in the winter (Fig. 2d).

Besides urban emissions from solvent and fossil fuel use, biomass burning is an important source of aromatics in many parts of the world (Lewis et al., 2013). The local dung or biomass burning (Duo et al., 2015; Xiao et al., 2015) may be potential sources of aromatics in the TP. Hence, DHOPA may come from the processing of biomass burning emission. Figure 7 exhibits the monthly variation of biomass burning tracer, levoglucosan during our sampling. The concentrations of levoglucosan ranged from $0.82 \mathrm{ng} \mathrm{m}^{-3}$ (October 2012) to $4.55 \mathrm{ng} \mathrm{m}^{-3}$ (April 2013) with a mean of $1.87 \pm 1.14 \mathrm{ng} \mathrm{m}^{-3}$. Apparently, the monthly variation trend of levoglucosan was quite different from that of DHOPA. And there was no correlation between DHOPA and levoglucosan $(p>0.05)$ (Fig. S6). These indicated that DHOPA at the $\mathrm{NC}$ site was not mainly from the processing of biomass burning emission. Since there were few anthropogenic sources near the remote $\mathrm{NC}$ site, the $\mathrm{SOA}_{\mathrm{A}}$ tracer should be not locally formed but mainly transported from upwind regions.

To check the potential source areas of anthropogenic emissions, the satellite data of population density (http: //sedac.ciesin.columbia.edu/theme/population), aerosol optical thickness (AOT, http://neo.sci.gsfc.nasa.gov/), tropospheric $\mathrm{NO}_{2}$ vertical column densities (VCD, http://avdc. gsfc.nasa.gov/), and surface CO (https://www2.acd.ucar.edu/ mopitt) were analysis on the global scale. As shown in Fig. S7a, the northern Indian subcontinent was the most populated region of the world, with a population density of more than 1000 persons per $\mathrm{km}^{2}$. Moreover, the plots of global 


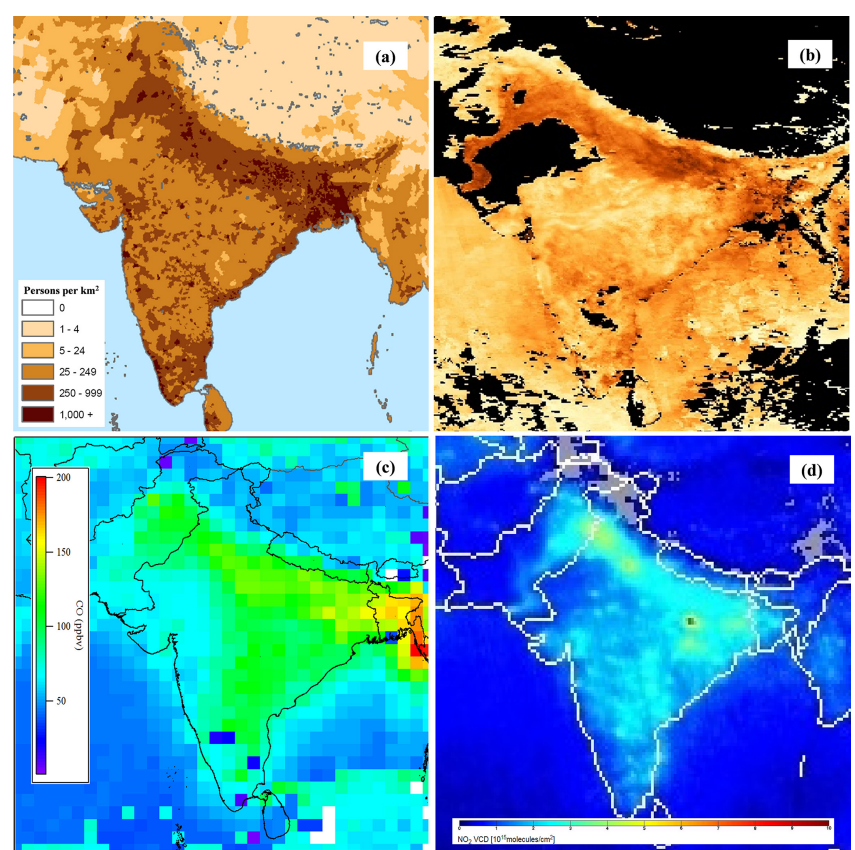

Figure 8. Spatial distribution of population density in 2000 (a), AOT (b), surface $\mathrm{CO}(\mathbf{c})$, and $\mathrm{NO}_{2}$ VCD (d) in May 2013 over the Indian subcontinent and the TP.

AOT, tropospheric $\mathrm{NO}_{2} \mathrm{VCD}$, and surface $\mathrm{CO}$ (Fig. S7b-d) all illustrated that the northern Indian subcontinent, including Bangladesh, Nepal, northeastern India, and northwestern India were the global hotspots of these anthropogenic pollutants. Compared with the northern Indian subcontinent, the TP exhibited extremely low population density and low levels of AOT, surface $\mathrm{CO}$, and $\mathrm{NO}_{2}$ VCD (Fig. 8a-d). Besides these satellite data, a recent study at a site in northwestern India (Indo-Gangetic plain) witnessed extremely high levels (up to $2065 \mathrm{ng} \mathrm{m}^{-3}$ ) of polycyclic aromatic hydrocarbons which were mainly formed from anthropogenic combustion processes (Dubey et al., 2015). All of these demonstrated that there were high anthropogenic emissions in the northern Indian subcontinent.

The TP features a monsoon climate (Cong et al., 2007; Ming et al., 2010; Zhao et al., 2013). Figure 9a presents the average trajectory of each cluster during our sampling in the whole year. The air masses over the NC were primarily from Bangladesh, Nepal and northeastern India (cluster 1, $32 \%$ ), northwestern India (Indo-Gangetic basin) (clusters $3-$ 6, $55 \%$ ), and the Taklimakan Desert (cluster 2, 13\%) during the sampling period. In the summer, the prevailing southerly winds (cluster 1, Fig. 9b) passed through the heavily polluted areas in Bangladesh and northeastern India, and could bring anthropogenic pollutants into the TP. Previous studies in the TP have witnessed the enrichment of anthropogenic metals (Cong et al., 2007) and the enhancement of carbonaceous aerosols (Ming et al., 2010; Zhao et al., 2013) under the influence of summer monsoon. Thus, the increase of DHOPA
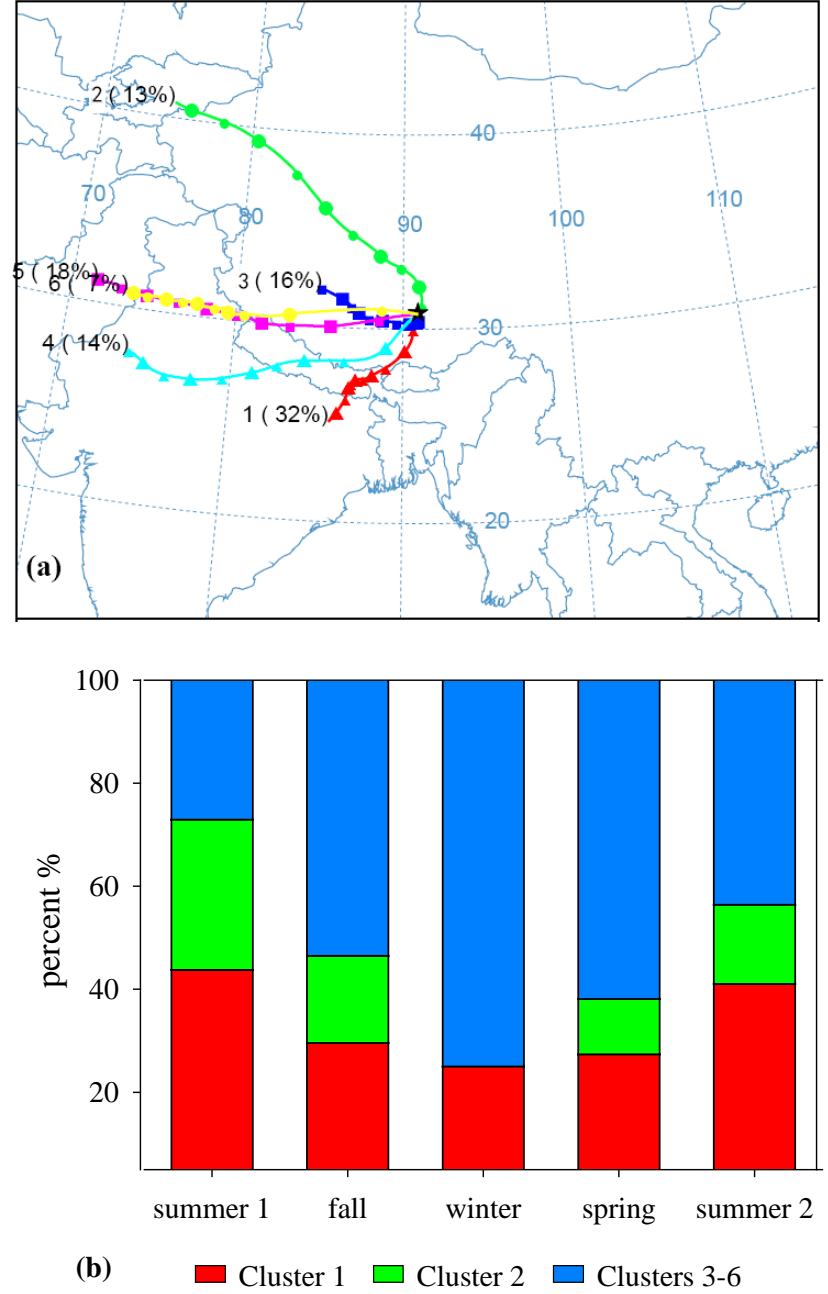

Figure 9. Cluster analyses of air masses at the NC site (a) and seasonal variations of clusters (b), based on 5-day backward trajectories during the sampling period. Summer 1 is from July to September 2012, fall is from October to November 2012, winter is from December 2012 to February 2013, spring is from March to May 2013, summer 2 is from June to July 2013.

levels at the NC site in the summer was mainly due to the transport of air pollutants from the upwind Bangladesh and northeastern India.

In the winter, the air masses over the NC site mainly originated from northwestern India (Indo-Gangetic basin) by the westerly winds (Fig. 9b). Compared with the summer samples, the winter samples underwent longer distance transport. Moreover, extremely low temperature in the winter could reduce DHOPA formation. Therefore, the levels of DHOPA were lower in the winter. It is worth noting that the mass fractions of DHOPA in all tracers significantly elevated in the winter (less than $2 \%$ in the summer but up to $10 \%$ in January, Fig. 2d), although its levels reduced. As described in Eqs. (3) and (6), temperature is an important factor controlling BVOCs emission. The drop of temperature from the 
summer (up to $10.2^{\circ} \mathrm{C}$ ) to the winter (low to $-16.7^{\circ} \mathrm{C}$ ) at the $\mathrm{NC}$ site would lead to the emission of isoprene and monoterpenes decreasing by 98 and $90 \%$, respectively. The elevated fractions of DHOPA in the winter samples suggested that the SOA contributions from aromatics would increase in the winter when BVOCs emission largely decreased.

\subsection{Source apportionment}

The SOA-tracer method developed by Kleindienst and coworkers was applied to attribute SOC at the NC site. The researchers performed chamber experiments to obtain the mass fraction of the tracers in $\mathrm{SOC}\left(f_{\mathrm{SOC}}\right)$ for individual precursor:

$f_{\mathrm{SOC}}=\frac{\sum_{i}[\mathrm{tri}]}{[\mathrm{SOC}]}$,

where $\sum_{i}[$ tri] is the total concentrations of the tracers for a certain precursor. [SOC] is the mass concentration of SOC. With these $f_{\text {SOC }}$ values and the measured SOA tracers in the ambient air, SOC from different precursors can be estimated in the atmosphere, with the assumption that the $f_{\text {SOC }}$ values in the chamber are the same as those in the ambient air. There is some degree of uncertainty in the SOA-tracer method due to the quantification with a single surrogate calibration standard (ketopinic acid) and the simplification of applying SOA tracers and conversion factors to calculate SOC in the ambient samples (Kleindienst et al., 2007). However, this method has been widely applied to attribute SOC from different precursors and proven to be able to provide reasonable results in the United States (Kleindienst et al., 2007; Stone et al., 2009; Lewandowski et al., 2013) and China (Hu et al., 2008; Guo et al., 2012; Peng et al., 2013; Ding et al., 2014). Lewandowski et al. (2008) found that the measured OC in the midwestern United States could be fully explained by primary OC from the chemical mass balance (CMB) model plus SOC from the SOA-tracer method, suggesting that the secondary organic tracer technique could be a valuable method for SOC estimation. Kleindienst et al. (2010) further compared the estimated SOC by the SOA-tracer method and other four independent methods (multiple regressions, $\mathrm{CMB}$, carbon isotope and EC-tracer) in the southeastern United States, and found that these five methods matched well. Our previous study in the Pearl River Delta found SOC levels estimated by the SOA-tracer method were not only consistent with but also correlated well with those by EC-tracer method in summer (Ding et al., 2012). The SOC apportionment results were also comparable between the SOA-tracer method and the positive matrix factorization (PMF) model in Hong Kong (Hu et al., 2010).

The $f_{\mathrm{SOC}}$ were reported as $0.155 \pm 0.039,0.023 \pm 0.0046$ and $0.00797 \pm 0.0026 \mu \mathrm{g} \mu \mathrm{gC} \mathrm{C}^{-1}$ for isoprene $\left(\mathrm{SOC}_{\mathrm{I}}\right), \beta$ caryophyllene $\left(\mathrm{SOC}_{\mathrm{C}}\right)$ and aromatics $\left(\mathrm{SOC}_{\mathrm{A}}\right)$, respectively (Kleindienst et al., 2007). In this study, the same set of SOA tracers as reported by Kleindienst et al. (2007) were used for

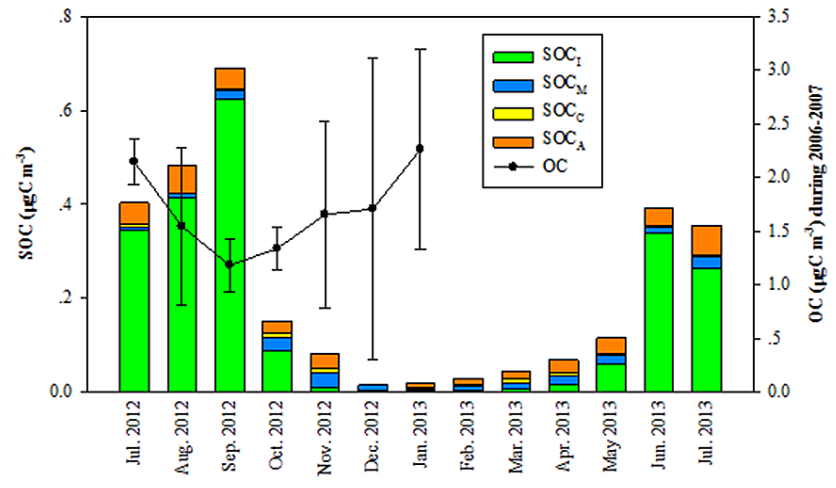

Figure 10. Seasonal variations of estimated SOC. OC data at the NC site during July 2006 to January 2007 were reported by Ming et al. (2010) and the error bar means one standard deviation in each month.

SOC estimation, including MGA and MTLs for $\mathrm{SOC}_{\mathrm{I}}, \beta$ caryophyllenic acid for $\mathrm{SOC}_{\mathrm{C}}$ and DHOPA for $\mathrm{SOC}_{\mathrm{A}}$. For monoterpene $\mathrm{SOC}\left(\mathrm{SOC}_{\mathrm{M}}\right)$, nine tracers were involved in the source profile (Kleindienst et al., 2007). However, only five of the nine $\mathrm{SOA}_{M}$ tracers were measured in the current study. Wang et al. (2013) compared the results from model prediction with field observation in the Pearl River Delta and pointed out that the SOA-tracer method would underestimate $\mathrm{SOA}_{\mathrm{M}}$, probably due to the mismatch of tracer compositions in the field and the source profile (Ding et al., 2014). To minimize the uncertainty caused by the mismatch in tracer compositions, the $f_{\mathrm{SOC}}$ with the same five $\mathrm{SOA}_{\mathrm{M}}$ tracers $\left(0.059 \mu \mathrm{g} \mathrm{g} \mathrm{C}^{-1}\right)$ was computed using the chamber data from another study by the same research group (Offenberg et al., 2007). The same $f_{\mathrm{SOC}}$ for $\mathrm{SOA}_{\mathrm{M}}$ was also applied to estimate $\mathrm{SOC}_{\mathrm{M}}$ in our previous study over China (Ding et al., 2014).

The uncertainty in the SOA-tracer method is induced from the analysis of organic tracers and the determination of the conversion factors. Based on the $E_{\mathrm{A}}$ values in Table S1, the uncertainties in the tracer analyses were within $40 \%$ for $\mathrm{SOA}_{\mathrm{I}}$ (only MGA and MTLs involved for SOC estimation), $95 \%$ for $\mathrm{SOA}_{\mathrm{M}}, 156 \%$ for $\mathrm{SOA}_{\mathrm{C}}$, and $91 \%$ for $\mathrm{SOA}_{\mathrm{A}}$. The uncertainties of $f_{\mathrm{SOC}}$ were reported to be $25 \%$ for isoprene, $48 \%$ for monoterpenes, $22 \%$ for $\beta$-caryophyllene and $33 \%$ for aromatics (Kleindienst et al., 2007; Lewandowski et al., 2013). Considering these factors, the uncertainties of SOC apportionment were calculated through error propagation. The RSD were $47 \%$ for $\mathrm{SOC}_{\mathrm{I}}, 106 \%$ for $\mathrm{SOC}_{\mathrm{M}}$, $157 \%$ for $\mathrm{SOC}_{\mathrm{C}}$, and $96 \%$ for $\mathrm{SOC}_{\mathrm{A}}$. On average, the RSD of the reconstructed SOC (sum of the four precursors) was $51 \pm 11 \%$.

Figure 10 presents the monthly variations of the reconstructed SOC. SOC was high in summer 2012 and declined from October to December. After that, it kept increasing from January to June. The total concentrations of SOC ranged from 0.02 to $0.69 \mu \mathrm{gC} \mathrm{m}^{-3}$ with an annual av- 
erage of $0.22 \pm 0.29 \mu \mathrm{gC} \mathrm{m}{ }^{-3}$. The available data of $\mathrm{OC}$ in total suspended particles at the $\mathrm{NC}$ site were reported in the range of 1.18 to $2.26 \mu \mathrm{gC} \mathrm{m}^{-3}$ during July 2006 to January 2007 (Ming et al., 2010). Since we did not measure OC in our size-segregated samples, the OC data reported by Ming et al. (2010) were used to calculate SOC fraction in OC (SOC/OC) from July to January. The calculated SOC/OC was on average $38 \%$ in the summer and up to $58 \%$ in September, suggesting that SOC was an important contributor to $\mathrm{OC}$ at the NC site during the summer (Ming et al., 2010). However, from the fall to the winter, the elevated OC and decreased SOC led to SOC/OC declining from $11 \%$ (in October) to $1 \%$ (in January), indicating that SOA from the four precursors had minor contributions to the elevated OC. Since the air masses during the fall to the winter mostly originated from Indo-Gangetic basin (clusters 3-6 in Fig. 9), primary pollutants emitted there could transport to the TP and have a significant impact on the air at the NC site. In addition, SOA from aqueous-phase reactions and primary OA aging could not be captured by the SOA-tracer method. Thus, the current results might underestimate the total amount of SOC, which partly explained the low OC shares of SOC at the NC site during the fall to the winter.

Biogenic SOC (sum of $\mathrm{SOC}_{\mathrm{I}}, \mathrm{SOC}_{\mathrm{M}}$, and $\mathrm{SOC}_{\mathrm{C}}$ ) dominated over $\mathrm{SOC}_{\mathrm{A}}$ at the $\mathrm{NC}$ site, on average accounting for $75 \%$ of the estimated SOC. In the summer, $\mathrm{SOC}_{\mathrm{I}}$ was the major contributor with the SOC shares of $81 \%$. From the fall to the spring, $\mathrm{SOC}_{\mathrm{M}}$ became the major contributor, on average contributing $38 \%$ to SOC. Although $\mathrm{SOC}_{\mathrm{A}}$ levels reduced in the winter, $\mathrm{SOC}_{\mathrm{A}}$ contributions elevated as high as $53 \%$ in January 2013. The elevated OC and the higher $\mathrm{SOC}_{\mathrm{A}}$ contributions in the winter samples (Fig. 10) implied that the transport of anthropogenic pollutants from the Indian subcontinent might have a significant influence on carbonaceous aerosols over the remote $\mathrm{NC}$ during winter.

\section{Conclusion}

Seasonal trends of SOA tracers and origins were studied in the remote TP for the first time. SOA I tracers represented the majority among these compounds. The significant temperature dependence of $\mathrm{SOA}_{I}$ tracers suggested that the seasonal variation of $\mathrm{SOA}_{\mathrm{I}}$ tracers at the NC site was mainly influenced by the isoprene emission. Due to the influence of temperature and relative humidity, the ratio of high- $\mathrm{NO}_{x}$ to low- $\mathrm{NO}_{x}$ products of $\mathrm{SOA}_{\mathrm{I}}$ (MGA/MTLs) was the highest in the winter and the lowest in the summer. The seasonal variation of $\mathrm{SOA}_{\mathrm{M}}$ tracers was impacted by monoterpenes emission and gas-particle partitioning. Due to the transport of air pollutants from the Indian subcontinent, DHOPA presented relatively higher concentrations in the summer and increased mass fractions in the winter. The SOA-tracer method was applied to estimated SOC from these four precursors. The annual average of SOC was $0.22 \pm 0.29 \mu \mathrm{gC} \mathrm{m}^{-3}$, with the biogenic SOC accounting for $75 \%$. In the summer, isoprene was the major precursor with its SOC shares of $81 \%$. In the winter when the emissions of biogenic precursors largely declined, the contributions of $\mathrm{SOC}_{\mathrm{A}}$ increased. At present, SOA origins and their seasonal variations are unclear in the remote high-elevation TP. The remote TP is connected to the densely populated Indian subcontinent. Our study implies that anthropogenic pollutants emitted there could be transported to the TP and influence SOC over the remote NC.

\section{The Supplement related to this article is available online at doi:10.5194/acp-15-8781-2015-supplement.}

Acknowledgements. This research was supported by the Strategic Priority Research Program of the Chinese Academy of Sciences (CAS) (XDA05100104/XDB05010200/XDA05100105), the National Science Foundation of China (41273116/41473099), and Youth Innovation Promotion Association, CAS.

Edited by: X. Xu

\section{References}

Claeys, M., Graham, B., Vas, G., Wang, W., Vermeylen, R., Pashynska, V., Cafmeyer, J., Guyon, P., Andreae, M. O., Artaxo, P., and Maenhaut, W.: Formation of secondary organic aerosols through photooxidation of isoprene, Science, 303, 1173-1176, 2004.

Claeys, M., Szmigielski, R., Kourtchev, I., Van der Veken, P., Vermeylen, R., Maenhaut, W., Jaoui, M., Kleindienst, T. E., Lewandowski, M., Offenberg, J. H., and Edney, E. O.: Hydroxydicarboxylic acids: Markers for secondary organic aerosol from the photooxidation of alpha-pinene, Environ. Sci. Technol., 41, 1628-1634, 2007.

Cong, Z. Y., Kang, S. C., Liu, X. D., and Wang, G. F.: Elemental composition of aerosol in the Nam Co region, Tibetan Plateau, during summer monsoon season, Atmos. Environ., 41, 11801187, 2007.

Ding, X., Zheng, M., Yu, L. P., Zhang, X. L., Weber, R. J., Yan, B., Russell, A. G., Edgerton, E. S., and Wang, X. M.: Spatial and seasonal trends in biogenic secondary organic aerosol tracers and water-soluble organic carbon in the southeastern United States, Environ. Sci. Technol., 42, 5171-5176, 2008.

Ding, X., Wang, X., and Zheng, M.: The influence of temperature and aerosol acidity on biogenic secondary organic aerosol tracers: Observations at a rural site in the central Pearl River Delta region, South China, Atmos. Environ., 45, 1303-1311, 2011.

Ding, X., Wang, X. M., Gao, B., Fu, X. X., He, Q. F., Zhao, X. Y., Yu, J. Z., and Zheng, M.: Tracer-based estimation of secondary organic carbon in the Pearl River Delta, south China, J. Geophys. Res.-Atmos., 117, D05313, doi:10.1029/2011jd016596, 2012.

Ding, X., Wang, X. M., Xie, Z. Q., Zhang, Z., and Sun, L. G.: Impacts of Siberian biomass burning on organic aerosols over the North Pacific Ocean and the Arctic: Primary and secondary organic tracers, Environ. Sci. Technol., 47, 3149-3157, 2013. 
Ding, X., He, Q.-F., Shen, R.-Q., Yu, Q.-Q., and Wang, X.-M.: Spatial distributions of secondary organic aerosols from isoprene, monoterpenes, $\beta$-caryophyllene, and aromatics over China during summer, J. Geophys. Res.-Atmos., 119, 11877-11891, 2014.

Donahue, N. M., Henry, K. M., Mentel, T. F., Kiendler-Scharr, A., Spindler, C., Bohn, B., Brauers, T., Dorn, H. P., Fuchs, H., Tillmann, R., Wahner, A., Saathoff, H., Naumann, K.-H., Moehler, O., Leisner, T., Mueller, L., Reinnig, M.-C., Hoffmann, T., Salo, K., Hallquist, M., Frosch, M., Bilde, M., Tritscher, T., Barmet, P., Praplan, A. P., DeCarlo, P. F., Dommen, J., Prevot, A. S. H., and Baltensperger, U.: Aging of biogenic secondary organic aerosol via gas-phase $\mathrm{OH}$ radical reactions, P. Natl. Acad. Sci. USA, 109, 13503-13508, 2012.

Dubey, J., Maharaj Kumari, K., and Lakhani, A.: Chemical characteristics and mutagenic activity of PM2.5 at a site in the IndoGangetic plain, India, Ecotoxicol. Environ. Safe, 114, 75-83, 2015.

Duo, B., Zhang, Y., Kong, L., Fu, H., Hu, Y., Chen, J., Li, L., and Qiong, A.: Individual particle analysis of aerosols collected at Lhasa City in the Tibetan Plateau, J. Environ. Sci., 29, 165-177, 2015.

Eddingsaas, N. C., Loza, C. L., Yee, L. D., Chan, M., Schilling, K. A., Chhabra, P. S., Seinfeld, J. H., and Wennberg, P. O.: a-pinene photooxidation under controlled chemical conditions - Part 2: SOA yield and composition in low- and high- $\mathrm{NO}_{\mathrm{x}}$ environments, Atmos. Chem. Phys., 12, 7413-7427, doi:10.5194/acp-12-74132012, 2012.

Froyd, K. D., Murphy, S. M., Murphy, D. M., de Gouw, J. A., Eddingsaas, N. C., and Wennberg, P. O.: Contribution of isoprenederived organosulfates to free tropospheric aerosol mass, P. Natl. Acad. Sci. USA, 107, 21360-21365, 2010.

Fu, P. Q., Kawamura, K., Chen, J., and Barrie, L. A.: Isoprene, monoterpene, and sesquiterpene oxidation products in the high Arctic aerosols during late winter to early summer, Environ. Sci. Technol., 43, 4022-4028, 2009.

Fu, P. Q., Kawamura, K., and Miura, K.: Molecular characterization of marine organic aerosols collected during a roundthe-world cruise, J. Geophys. Res.-Atmos., 116, D13302, doi:10.1029/2011jd015604, 2011.

Fu, P. Q., Kawamura, K., Chen, J., Charrière, B., and Sempéré, R.: Organic molecular composition of marine aerosols over the Arctic Ocean in summer: contributions of primary emission and secondary aerosol formation, Biogeosciences, 10, 653-667, doi:10.5194/bg-10-653-2013, 2013.

Glasius, M., Lahaniati, M., Calogirou, A., Di Bella, D., Jensen, N. R., Hjorth, J., Kotzias, D., and Larsen, B. R.: Carboxylic acids in secondary aerosols from oxidation of cyclic monoterpenes by ozone, Environ. Sci. Technol., 34, 1001-1010, 2000.

Gómez-González, Y., Wang, W., Vermeylen, R., Chi, X., Neirynck, J., Janssens, I. A., Maenhaut, W., and Claeys, M.: Chemical characterisation of atmospheric aerosols during a 2007 summer field campaign at Brasschaat, Belgium: sources and source processes of biogenic secondary organic aerosol, Atmos. Chem. Phys., 12, 125-138, doi:10.5194/acp-12-125-2012, 2012.

Guenther, A., Hewitt, C. N., Erickson, D., Fall, R., Geron, C., Graedel, T., Harley, P., Klinger, L., Lerdau, M., Mckay, W. A., Pierce, T., Scholes, B., Steinbrecher, R., Tallamraju, R., Taylor, J., and Zimmerman, P.: A global-model of natural volatile organic-compound emissions, J. Geophys. Res.-Atmos., 100 8873-8892, 1995.

Guenther, A. B., Zimmerman, P. R., Harley, P. C., Monson, R. K., and Fall, R.: Isoprene and monoterpene emission rate variability - Model evaluations and sensitivity analyses, J. Geophys. Res.Atmos., 98, 12609-12617, 1993.

Guo, S., Hu, M., Guo, Q., Zhang, X., Zheng, M., Zheng, J., Chang, C. C., Schauer, J. J., and Zhang, R.: Primary sources and secondary formation of organic aerosols in Beijing, China, Environ. Sci. Technol., 46, 9846-9853, 2012.

Hu, D., Bian, Q., Li, T. W. Y., Lau, A. K. H., and Yu, J. Z.: Contributions of isoprene, monoterpenes, $\beta$-caryophyllene, and toluene to secondary organic aerosols in Hong Kong during the summer of 2006, J. Geophys. Res.-Atmos., 113, D22206, doi:10.1029/2008jd010437, 2008.

Hu, D., Bian, Q., Lau, A. K. H., and Yu, J. Z.: Source apportioning of primary and secondary organic carbon in summer $\mathrm{PM}_{2.5}$ in Hong Kong using positive matrix factorization of secondary and primary organic tracer data, J. Geophys. Res.-Atmos., 115, D16204, doi:10.1029/2009JD012498, 2010.

Hu, Q. H., Xie, Z. Q., Wang, X. M., Kang, H., He, Q. F., and Zhang, P.: Secondary organic aerosols over oceans via oxidation of isoprene and monoterpenes from Arctic to Antarctic, Sci. Rep., 3, 2280, doi:10.1038/srep02280, 2013.

Jang, M. S., Czoschke, N. M., Lee, S., and Kamens, R. M.: Heterogeneous atmospheric aerosol production by acid-catalyzed particle-phase reactions, Science, 298, 814-817, 2002.

Jaoui, M., Kleindienst, T. E., Lewandowski, M., Offenberg, J. H., and Edney, E. O.: Identification and quantification of aerosol polar oxygenated compounds bearing carboxylic or hydroxyl groups. 2. Organic tracer compounds from monoterpenes, Environ. Sci. Technol., 39, 5661-5673, 2005.

Jaoui, M., Lewandowski, M., Kleindienst, T. E., Offenberg, J. H., and Edney, E. O.: $\beta$-Caryophyllinic acid: An atmospheric tracer for $\beta$-caryophyllene secondary organic aerosol, Geophys. Res. Lett., 34, L05816, doi:10.1029/2006g1028827, 2007.

Kim, J.-C.: Factors controlling natural VOC emissions in a southeastern US pine forest, Atmos. Environ., 35, 3279-3292, 2001.

Kleindienst, T. E., Jaoui, M., Lewandowski, M., Offenberg, J. H., Lewis, C. W., Bhave, P. V., and Edney, E. O.: Estimates of the contributions of biogenic and anthropogenic hydrocarbons to secondary organic aerosol at a southeastern US location, Atmos. Environ., 41, 8288-8300, 2007.

Kleindienst, T. E., Lewandowski, M., Offenberg, J. H., Edney, E. O., Jaoui, M., Zheng, M., Ding, X., and Edgerton, E. S.: Contribution of primary and secondary sources to organic aerosol and $\mathrm{PM}_{2.5}$ at SEARCH network sites, J. Air Waste Manage., 60 , 1388-1399, 2010.

Lewandowski, M., Jaoui, M., Offenberg, J. H., Kleindienst, T. E., Edney, E. O., Sheesley, R. J., and Schauer, J. J.: Primary and secondary contributions to ambient $\mathrm{PM}_{2.5}$ in the midwestern United States, Environ. Sci. Technol., 42, 3303-3309, 2008.

Lewandowski, M., Piletic, I. R., Kleindienst, T. E., Offenberg, J. H., Beaver, M. R., Jaoui, M., Docherty, K. S., and Edney, E. O.: Secondary organic aerosol characterisation at field sites across the United States during the spring-summer period, Int. J. Environ. Anal. Chem., 93, 1084-1103, 2013.

Lewis, A. C., Evans, M. J., Hopkins, J. R., Punjabi, S., Read, K. A., Purvis, R. M., Andrews, S. J., Moller, S. J., Carpenter, L. 
J., Lee, J. D., Rickard, A. R., Palmer, P. I., and Parrington, M.: The influence of biomass burning on the global distribution of selected non-methane organic compounds, Atmos. Chem. Phys., 13, 851-867, doi:10.5194/acp-13-851-2013, 2013.

Li, J. J., Wang, G. H., Wang, X. M., Cao, J. J., Sun, T., Cheng, C. L., Meng, J. J., Hu, T. F., and Liu, S. X.: Abundance, composition and source of atmospheric $\mathrm{PM}_{2.5}$ at a remote site in the Tibetan Plateau, China, Tellus B, 65, 20281, doi:10.3402/tellusb.v65i0.20281, 2013.

Lin, Y. H., Zhang, H. F., Pye, H. O. T., Zhang, Z. F., Marth, W. J., Park, S., Arashiro, M., Cui, T. Q., Budisulistiorini, H., Sexton, K. G., Vizuete, W., Xie, Y., Luecken, D. J., Piletic, I. R., Edney, E. O., Bartolotti, L. J., Gold, A., and Surratt, J. D.: Epoxide as a precursor to secondary organic aerosol formation from isoprene photooxidation in the presence of nitrogen oxides, P. Natl. Acad. Sci. USA, 110, 6718-6723, 2013.

Ming, J., Xiao, C. D., Sun, J. Y., Kang, S. C., and Bonasoni, P.: Carbonaceous particles in the atmosphere and precipitation of the Nam Co region, central Tibet, J. Environ. Sci., 22, 17481756, 2010.

Odum, J. R., Hoffmann, T., Bowman, F., Collins, D., Flagan, R. C., and Seinfeld, J. H.: Gas/particle partitioning and secondary organic aerosol yields, Environ. Sci. Technol., 30, 2580-2585, 1996.

Offenberg, J. H., Lewis, C. W., Lewandowski, M., Jaoui, M., Kleindienst, T. E., and Edney, E. O.: Contributions of toluene and $\alpha$ pinene to SOA formed in an irradiated toluene $/ \alpha$-pinene/ $/ \mathrm{NO}_{x} /$ air mixture: Comparison of results using ${ }^{14} \mathrm{C}$ content and SOA organic tracer methods, Environ. Sci. Technol., 41, 3972-3976, 2007.

Paulot, F., Crounse, J. D., Kjaergaard, H. G., Kurten, A., St Clair, J. M., Seinfeld, J. H., and Wennberg, P. O.: Unexpected epoxide formation in the gas-phase photooxidation of isoprene, Science, 325, 730-733, 2009.

Peng, J. L., Li, M., Zhang, P., Gong, S. Y., Zhong, M. A., Wu, M. H., Zheng, M., Chen, C. H., Wang, H. L., and Lou, S. R.: Investigation of the sources and seasonal variations of secondary organic aerosols in PM2.5 in Shanghai with organic tracers, Atmos. Environ., 79, 614-622, 2013.

Piccot, S. D., Watson, J. J., and Jones, J. W.: A global inventory of volatile organic-compound emissions from anthropogenic sources, J. Geophys. Res.-Atmos., 97, 9897-9912, 1992.

Robinson, A. L., Donahue, N. M., Shrivastava, M. K., Weitkamp, E. A., Sage, A. M., Grieshop, A. P., Lane, T. E., Pierce, J. R., and Pandis, S. N.: Rethinking organic aerosols: Semivolatile emissions and photochemical aging, Science, 315, 1259-1262, 2007.

Sheehan, P. E. and Bowman, F. M.: Estimated effects of temperature on secondary organic aerosol concentrations, Environ. Sci. Technol., 35, 2129-2135, 2001.

Stone, E. A., Zhou, J., Snyder, D. C., Rutter, A. P., Mieritz, M., and Schauer, J. J.: A comparison of summertime secondary organic aerosol source contributions at contrasting urban locations, Environ. Sci. Technol., 43, 3448-3454, 2009.

Stone, E. A., Nguyen, T. T., Pradhan, B. B., and Dangol, P. M.: Assessment of biogenic secondary organic aerosol in the Himalayas, Environ. Chem., 9, 263-272, 2012.
Surratt, J. D., Lewandowski, M., Offenberg, J. H., Jaoui, M., Kleindienst, T. E., Edney, E. O., and Seinfeld, J. H.: Effect of acidity on secondary organic aerosol formation from isoprene, Environ. Sci. Technol., 41, 5363-5369, 2007.

Surratt, J. D., Chan, A. W. H., Eddingsaas, N. C., Chan, M. N., Loza, C. L., Kwan, A. J., Hersey, S. P., Flagan, R. C., Wennberg, P. O., and Seinfeld, J. H.: Reactive intermediates revealed in secondary organic aerosol formation from isoprene, P. Natl. Acad. Sci. USA, 107, 6640-6645, 2010.

Szmigielski, R., Surratt, J. D., Gómez-González, Y., Veken, P. V. d., Kourtchev, I., Vermeylen, R., Blockhuys, F., Jaoui, M., Kleindienst, T. E., Lewandowski, M., Offenberg, J. H., Edney, E. O., Seinfeld, J. H., Maenhaut, W., and Claeys, M.: 3-Methyl1,2,3-butanetricarboxylic acid: An atmospheric tracer for terpene secondary organic aerosol, Geophys. Res. Lett., 34, L24811, doi:10.1029/2007GL031338, 2007.

van Eijck, A., Opatz, T., Taraborrelli, D., Sander, R., and Hoffmann, T.: New tracer compounds for secondary organic aerosol formation from beta-caryophyllene oxidation, Atmos. Environ., 80, 122-130, 2013.

von Schneidemesser, E., Schauer, J. J., Hagler, G. S. W., and Bergin, M. H.: Concentrations and sources of carbonaceous aerosol in the atmosphere of Summit, Greenland, Atmos. Environ., 43, 41554162, 2009.

Wang, S. Y., Wu, D. W., Wang, X. M., Fung, J. C. H., and Yu, J. Z.: Relative contributions of secondary organic aerosol formation from toluene, xylenes, isoprene, and monoterpenes in Hong Kong and Guangzhou in the Pearl River Delta, China: an emission-based box modeling study, J. Geophys. Res.-Atmos., 118, 507-519, 2013.

Xiao, Q., Saikawa, E., Yokelson, R. J., Chen, P., Li, C., and Kang, S.: Indoor air pollution from burning yak dung as a household fuel in Tibet, Atmos. Environ., 102, 406-412, 2015.

Xua, B., Cao, J., Hansen, J., Yao, T., Joswia, D. R., Wang, N., Wu, G., Wang, M., Zhao, H., Yang, W., Liu, X., and He, J.: Black soot and the survival of Tibetan glaciers, P. Natl. Acad. Sci. USA, 106, 22114-22118, 2009.

Zhang, H., Surratt, J. D., Lin, Y. H., Bapat, J., and Kamens, R. M.: Effect of relative humidity on SOA formation from isoprene/NO photooxidation: enhancement of 2-methylglyceric acid and its corresponding oligoesters under dry conditions, Atmos. Chem. Phys., 11, 6411-6424, doi:10.5194/acp-11-6411-2011, 2011.

Zhao, Z. Z., Cao, J. J., Shen, Z. X., Xu, B. Q., Zhu, C. S., Chen, L. W. A., Su, X. L., Liu, S. X., Han, Y. M., Wang, G. H., and Ho, K. F.: Aerosol particles at a high-altitude site on the Southeast Tibetan Plateau, China: Implications for pollution transport from South Asia, J. Geophys. Res.-Atmos., 118, 11360-11375, 2013.

Zhou, S. Q., Kang, S. C., Chen, F., and Joswiak, D. R.: Water balance observations reveal significant subsurface water seepage from Lake Nam Co, south-central Tibetan Plateau, J. Hydrol., 491, 89-99, 2013. 